\title{
Нестандартна інтраопераційна ситуація при операційному лікуванні пізньої рубцевої стриктури езофагоколоанастомозу після раніше проведеної товстокишкової езофагопластики
}

\begin{abstract}
Мета роботи: виявити особливості діагностики та лікування післяопераційних рубцевих стриктур стравохідно-органних анастомозів та вихід з нестандартної інтраопераційної ситуації. Стаття присвячена клінічному спостереженню нестандартної інтраопераційної ситуації при лікуванні пацієнта з пізньою рубцевою стриктурою езофагоколоанастомозу після проведеної товстокишкової езофагопластики.
\end{abstract}

Ключові слова: післяопераційна стриктура стравоходу; лікувальна тактика.

Одними із пізніх ускладнень реконструктивно-відновних операційних втручань на стравоході у віддалений післяопераційний період є виникнення післяопераційних рубцевих стриктур, які займають друге місце серед причин виникнення стенозуючих захворювань стравоходу [1, 3, 4, 6]. За даними деяких авторів (Мовчан Б.Б., 2007; Савві С.О., 2011) частота виникнення стриктур верхнього, шийного анастомозу залежить від багатьох факторів: порушень техніки формування анастомозу, використання того чи іншого трансплантата, шляху його проведення, застосування відповідного шовного матеріалу, апаратного чи механічного шва, чи виникала неспроможність в післяопераційному періоді. Підвищена частота виникнення стриктур стравохідно-органних анастомозів спостерігається при використанні як трансплантата шлункової трубки (30 \%), ніж при езофагопластиці з використанням товстої кишки $(8,7 \%)$ або тонкої кишки (до 1 \%), як правило, вона виникає на рівні яремної вирізки чи рукоятки груднини при загруднинному проведенні трансплантата [2, 5].

Наведено клінічний випадок лікування даного ускладнення, яке виникло у хворого через 6 років після проведеної езофагопластики товстою кишкою, і вихід з нестандартної інтраопераційної ситуації.

Мета роботи: виявлення особливостей діагностики та лікування післяопераційних рубцевих стриктур стравохідно-органних анастомозів та вихід з нестандартної інтраопераційної ситуації.

У клініку хірургії № 1 Вінницького національного медичного університету імені М. І. Пирогова був госпіталізований хворий X., 66 років, медична карта стаціонарного хворого № 10419. Раніше хворий перебував на стаціонарному лікуванні у відділенні торакальної хірургії ВОКЛ імені М. І. Пиро- гова з 19.08.09 р. до 18.09.09 р. із приводу рубцевої стриктури стравоходу і стенозу виходу зі шлунка внаслідок хімічного опіку з повною непрохідністю стравоходу. 3 анамнезу відомо, що хворому була виконана субтотальна езофагопластика сегментом ободової кишки зі збереженням кровопостачання за рахунок лівої ободовокишкової артерії, сформовано гастроентероанастомоз та гастростому за Кадером. Хворого виписали на 22 добу.

Протягом наступних шести років стан хворого був задовільний, і результат лікування розцінювався як добрий. Проте у червні 2015 р. з'явились скарги на утруднене ковтання та проходження твердої їжі, пізніше хворий взагалі не міг їсти тверду їжу, окрім напіврідкої та рідкої. Стан хворого погіршувався, з'явились явища кахексії. Звернувся за консультацією та був госпіталізований (рис. 1). При дообстеженні встановлено такі результати лабораторних та інструментальних методів дослідження від 15.07.15 р.

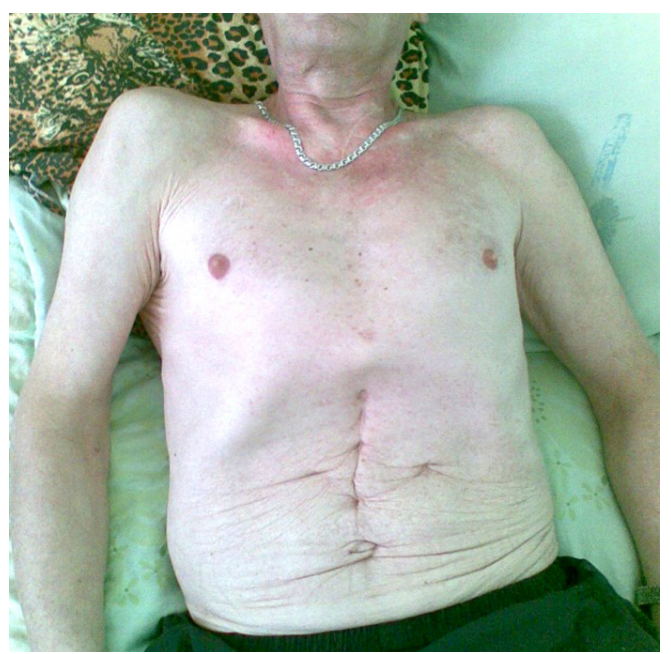

Рис. 1. Хворий Х., 66 років. Стан після перенесеної товстокишкової езофагопластики у 2009 р. 
Загальний аналіз крові: гемоглобін - 105 г/л, еритроцити $3,5 \times 10^{12} /$ л, лейкоцити $-7,0 \times 10^{9} /$ л, кількість паличкоядерних нейтрофілів - 3, лімфоцити $-1,5 \times 10^{9} /$ л, ШОЕ - 30 мм/год. Калій крові - 3,6 ммоль/л, натрій - 137 ммоль/л, загальний білок - 57 г/л, альбумін - 30 г/л, загальний білірубін - 8,6 мкмоль/л, фібриноген - 3,7 г/л, протромбіновий індекс - $92 \%$, сечовина - 5,0 ммоль/л, креатинін - 0,05 ммоль/л. Загальний аналіз сечі: колір - солом'яно-жовтий, реакція - кисла, питома вага - 1018, білок - 0,033 г/л, епітелій плоский - 5-6 в полі зору, лейкоцити - 3-5 в полі зору, еритроцити - 0-1 в полі зору. При виконанні езофагоскопії виявлено стриктуру езофагоколоанастомозу, яку пройти езофагоскопом не вдалося. Виконано контрастне рентгенологічне дослідження “штучного” стравоходу з тріомбрастом: виявлено стриктуру шийного, езофагоколоанастомозу, повну непрохідність стравоходу, його супрастенотичне розширення (рис. 2).

Таким чином, при дообстеженні, виконанні діагностичного алгоритму, при проведенні контрастного дослідження ШКТ виявлено стриктуру езофагоколоанастомозу, повну непрохідність стравоходу. Діагноз при госпіталізації: рубцева стриктура стравохіднотовстокишкового анастомозу. Повна непрохідність стравоходу. IXC. Атеросклеротичний міокардіосклероз, аортосклероз, CH I, гіпертонічна хвороба II, 2 ст., ризик IV, гіпертрофія лівого шлуночка. Трофічний статус хворого - помірний ступінь.виснаження. Спроби виконати бужування та стентування були невдалими. Тому хворому було запропоноване операційне втручання, а саме: езофагопластику власними тканинами. Згідно з прогностичною шкалою встановлено низький ступінь ризику розвитку післяопераційних ускладнень.

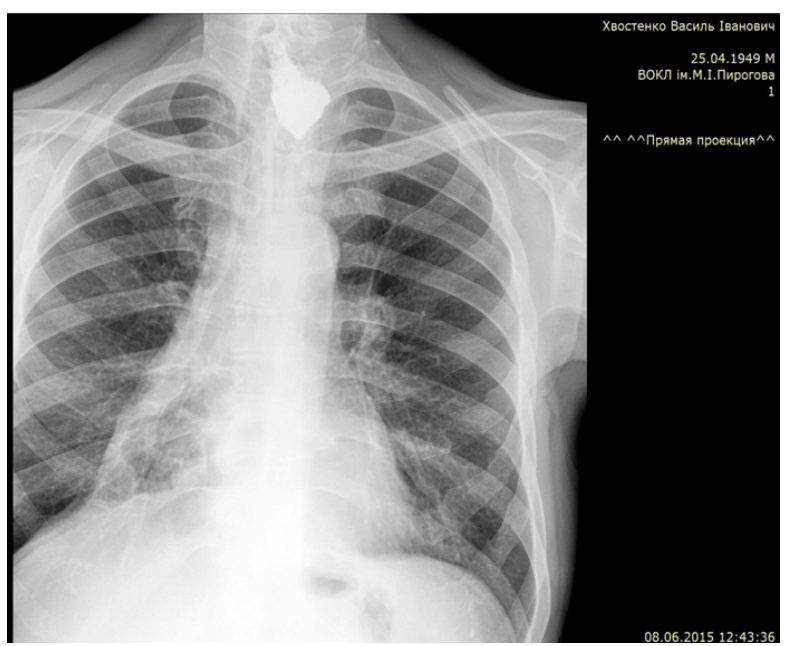

Рис. 2. Контрастна езофагограма хворого Х., 66 років. Стриктура езофагоколоанастомозу. Повна непрохідність стравоходу.
У передопераційному періоді проводили інтенсивну трансфузійну терапію з контролем водно-електролітного балансу, білкового, вуглеводного обмінів. Також призначали антибактеріальну, протизапальну, антисекреторну та антирефлюксну терапію. Даний етап проводили спільно із лікарем-реаніматологом. 22.07.15 р. виконано циркулярну резекцію ділянки стриктури стравоходу (анастомозу) з пластикою “кінець у бік”. Після виконання лівобічної цервікотомії виявлено ділянку супрастенотичного розширення. Дистальніше ділянку стриктури та анастомозу не вдалося виявити (можливо, із-за скорочення кишки). I після тривалого пошуку анастомозу прийнято рішення виконати поздовжню стернотомію (рис. 3). Встановлено, що відстань від супрастенотичного розширення до трансплантата складає 5-6 см, а анастомоз у вигляді 2 мм рубця. 3 технічними труднощами був виділений стравохіднотовстокишковий анастомоз та додатково мобілізований із зрощень товстокишковий трансплантат (рис. 4,5$)$.

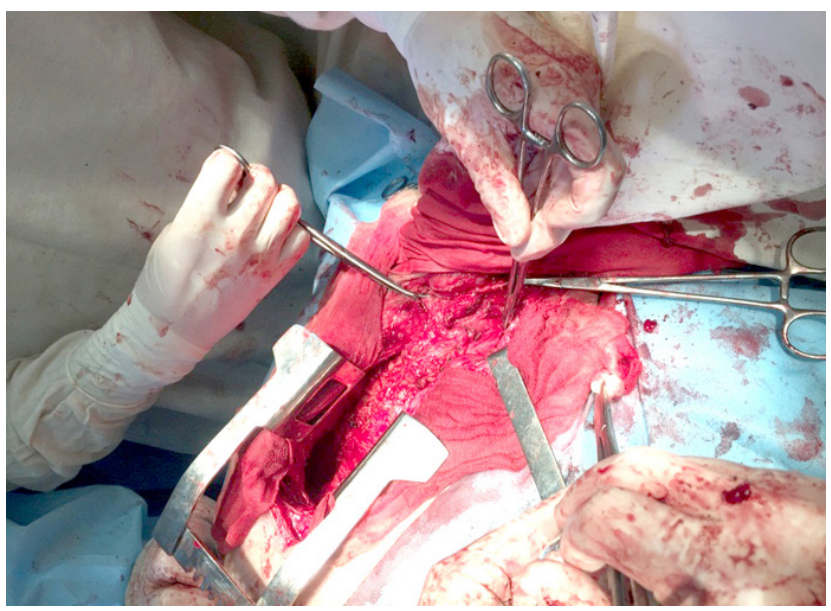

Рис. 3. Хворий Х., виконання лівобічної цервікотомії та поздовжньої стернотомії.

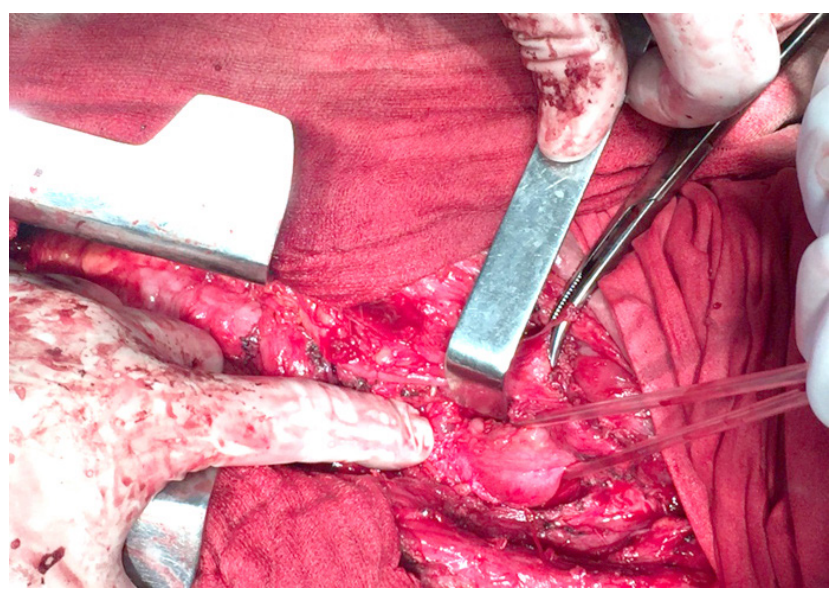

Рис. 4. Хворий Х., виділення ділянки стравохіднотовстокишкового анастомозу зі стриктурою та його резекція. 


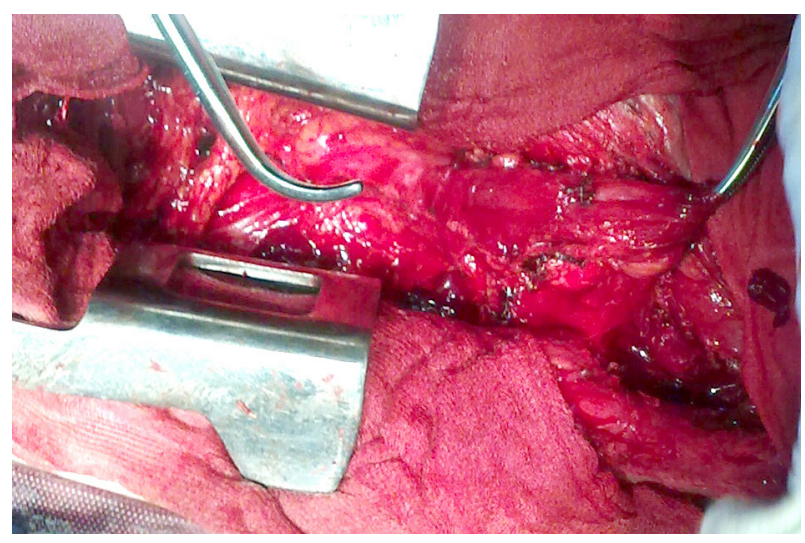

Рис. 5. Хворий Х., додаткова мобілізація товстокишкового трансплантата.

Виконали резекцію стравохіднотовстокишкового анастомозу, додатково мобілізувавши товстокишковий трансплантат, щоб був достатньої довжини. Сформували новий езофагоколоанастомоз “кінець у бік” із попереднім заведенням шлункового зонда № 21 (рис. 6).

Операцію завершили дренуванням середостіння та ділянки лівобічної цервікотомії спареними поліхлорвініловими дренажами (рис. 7, 8).

У післяопераційному періоді продовжували виконання запропонованої інфузійної терапії протягом 7 діб. Проводили ентеральне харчування сумішшю "Peptamen" через назогастральний зонд. Хворому проводили антибактеріальну терапію (цефтазидим - 1,0 г 2 рази на добу, метронідазол - 100 мл 2 рази на добу), антикоагулянтну (еноксапарин 0,4 мл підшкірно 1 раз на добу) та інфузійно-детоксикаційну терапію. На 9-ту добу перевірили спроможність езофагоколоанастомозу шляхом проведення рентгенологічного дослідження з пероральним введенням тріомбрасту (рис. 9).

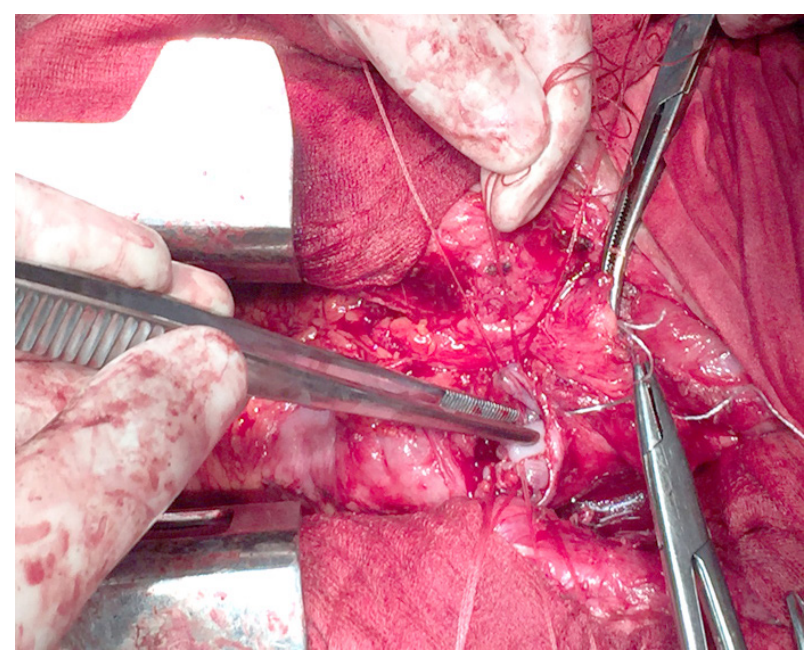

Рис. 6. Хворий Х., формування “нового” езофагоколоанастомозу “кінець у бік” із попереднім заведенням назогастрального зонда.

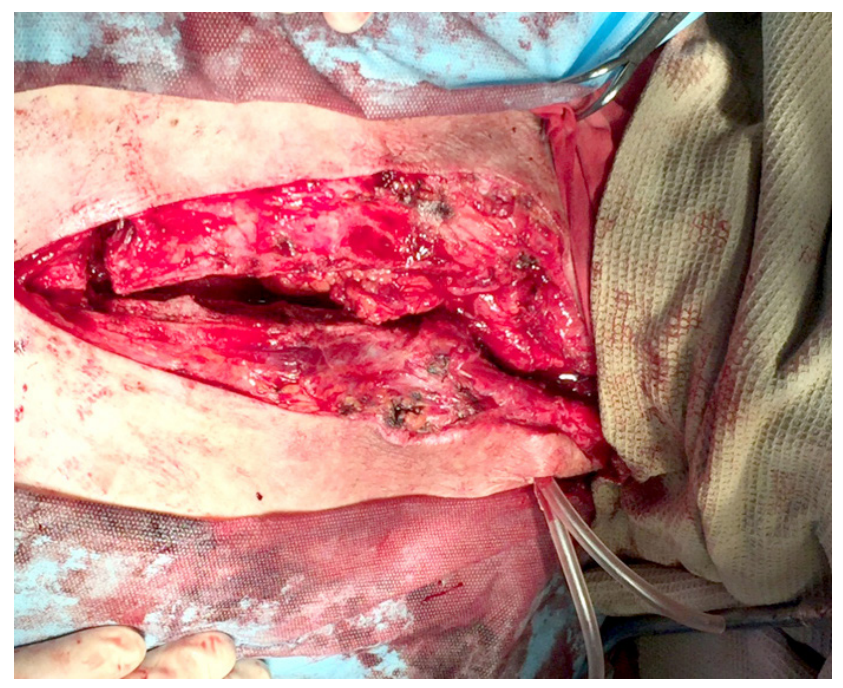

Рис. 7. Хворий Х., кінцевий вигляд операції, дренування ділянки “нового” езофагоколоанастомозу.

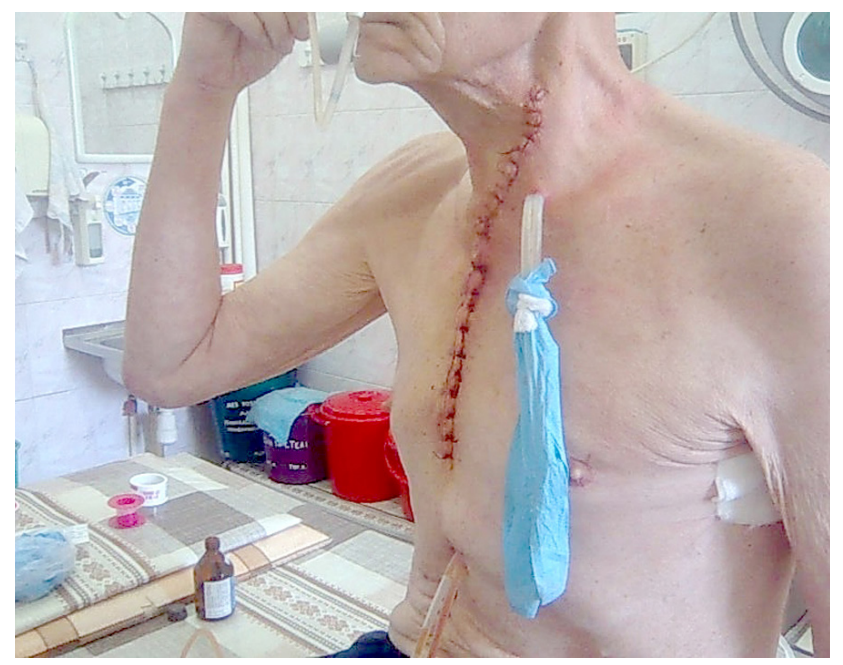

Рис. 8. Хворий Х., 6-та доба післяопераційного періоду.

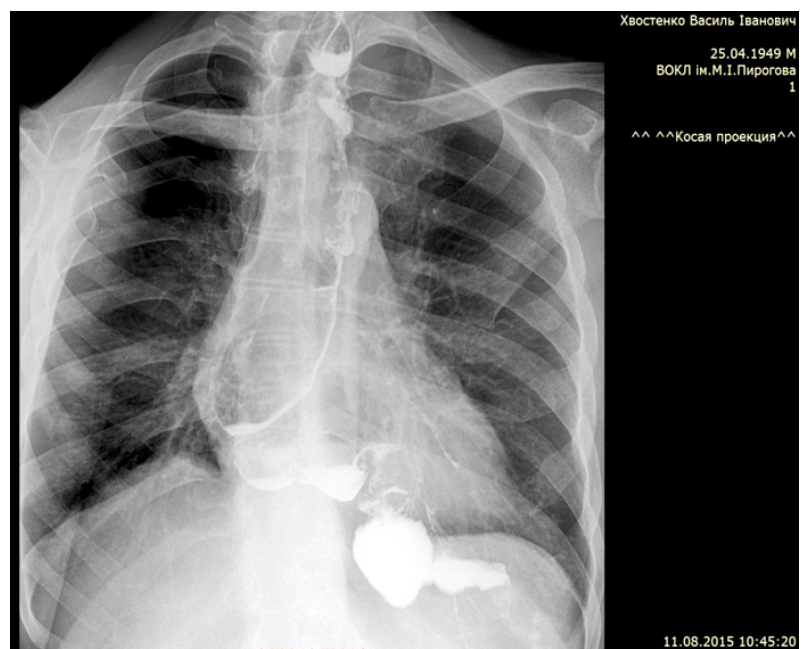

Рис. 9. Хворий Х., контрастна рентгенограма після операції. Контраст не виходить за межі езофагоколоанастомозу, який є прохідним. 
Після цього дозволили спочатку пити, а потім приймати їжу. Дренажі видалено на 12-ту і 14ту доби. Післяопераційні рани загоїлись первинним натягом. На 16-ту добу хворий у задовільному стані був виписаний.

Таким чином, наведений клінічний приклад ілюструє правильність обраної хірургічної так-

\section{СПИСОК ЛІТЕРАТУРИ}

1. Багиров М. М. Применение тотальной и субтотальной эзофагопластики в лечении рубцового стеноза пищевода / М. М. Багиров, Р. И. Верещако // Клінічна хірургія. - 2008. - № 8. - С. 11-15.

2. Мовчан Б. Б. Пути улучшения результатов эзофагопластики / Б. Б. Мовчан // Клін. хірургія. - 2007. - № 2-3. - С. 50.

3. Восстановительные операции по поводу рубцовой послеожоговой стриктуры пищевода / В. Ф. Саенко, С. А. Андреещев, П. Н. Кондратенко, С. Д. Мясоедов // Клінічна хірургія. - 2002. - №. 5-6. - С. 4.

4. Хирургическое лечение рубцовых послеожоговых стрик- тики при нестандартній інтраопераційній ситуації, що виникла, з приводу операційного лікування пізньої рубцевої стриктури езофагоколоанастомозу. Дотримання чіткого діагностичного алгоритму допомагає швидко встановити даний діагноз та вести хворого в післяопераційному періоді.

\title{
REFERENCES
}

1. Bagirov, M.M., \& Vereshchako, R.I. (2008). Primenenie totalnoy $i$ subtotalnoy ezofagoplastiki $v$ lechenii rubtsovogo stenoza pishchevoda [Use of total and subtotal esophagoplasty in treatment of corrosive esophageal strictures]. Klinichna khirurhiia - Clinical Surgery, 8, 11-15 [in Russian].

2. Movchan, B.B. (2007). Puti uluchsheniya resultatov ezofagoplastiki [The ways of improvement of esophagoplasty results]. Klinichna khirurhiia - Clinical Surgery, 2-3, 50 [in Russian].

3. Saenko, V.F., Andreeshchev, S.F., Kondratenko, P.N., \& Miasoedov, S.D. (2002). Vostanovitelnye operatsyi po povodu rubtsovoy posleozhogovoy striktury pishchevoda [Reconstructive operations for post-burn corrosive esophageal strictures]. Klinichna khirurhiia - Clinical Surgery, 5-6, 4 [in Russian]. тур пищевода и выходного отдела желудка / В. В. Бойко, И. А. Криворучко, С. А. Савви [та ін.] // Вісник невідкладної і відновної медицини. - 2002. - Т. 3, № 2. - С. 187-189.

5. Dantas R. O. Motility of the transverse colon used for esophageal replacement / R. O. Dantas, R. C. Matede // J. Clin. Gastroenterol. - 2002. - Vol. 34, № 3. - P. 225-228.

6. The use of self-expanding silicone stents in esophagectomy strictures: less cost and more efficiency / R. C. Martin, C. Woodall, R. Duvall, C. R. Scoggins // Ann. Thorac. Surg. - 2008. - Vol. 86, No. 2. - P.436-440 [abstract PMID: 18640310]. - Режим доступу: www.ncbi.nih.gov.
4. Boyko, V.V., Krivoruchko, S.A., \& Savvi, S.A. (2002). Khirurgicheskoe lechenie rubtsovykh posleozhogovykh striktur pishchevoda i vykhodnogo otdela zheludka [Surgical treatment of post-burn corrosive esophageal and antral strictures]. Visnyk nevidkladnoi i vidnovnoi medytsyny - Journal of Emergency and Reconstructive Medicine, 2, 187-189 [in Russian].

5. Dantas, R.O., \& Matede, R.C. (2002). Motility of the transverse colon used for esophageal replacement. J. Clin. Gastroenterol., 3, 225-228.

6. Martin, R.C., Woodall, C., Duvall, R., \& Scoggins, C.R. (2008). The use of self-expanding silicone stents in esophagectomy strictures: less cost and more efficiency. Ann. Thorac. Surg., 2, 436-440.

\section{NON-STANDARD INTRAOPERATIVE SITUATION AT SURGICAL TREATMENT OF LATE CICATRICIAL STRICTURE OF ESOPHAGOCOLOANASTOMOSIS AFTER PREVIOUS CARRIED-OUT LARGE INTES- TINE ESOPHAGEAL REPLACEMENT}

\begin{abstract}
The aim of the work: to identify the features of diagnostics and treatment of postoperative scar strictures of esophageal-organ anastomosis and the emergence from non-standard intraoperative situation. The article is devoted to the clinical observation of non-standard intraoperative situation at surgical treatment of the patient with late scar stricture of esophagocoloanastomosis after the carried-out large intestine esophageal replacement.
\end{abstract}

Key words: postoperative esophageal stricture; medical tactic. 
В. А. ШАПРИНСКИЙ, В. Ф. КРИВЕЦКИЙ, В. И. ПОЛИЩУК, Е. В. ШАПРИНСКИЙ

Винницкий национальный медицинский университет имени Н. И. Пирогова

НЕСТАНДАРТНАЯ ИНТРАОПЕРАЦИОННАЯ СИТУАЦИЯ ПРИ ОПЕРАТИВНОМ ЛЕЧЕНИИ ПОЗДНЕЙ РУБЦОВОЙ СТРИКТУРЫ ЭЗОФАГОКОЛОАНАСТОМОЗА ПОС.ЛЕ РАНЕЕ ПРОВЕДЕННОЙ ТОЛСТОКИШЕЧНОЙ ЭЗОФАГОПЛАСТИКИ

Цель работы: выявить особенности диагностики и лечения послеоперационных рубцовых стриктур пищеводно-органных анастомозов и выход из нестандартной интраоперационной ситуации.

Статья посвящена клиническому наблюдению нестандартной интраоперационной ситуации при лечении пациента с поздней рубцовой стриктурой эзофагоколоанастомоза после проведенной толстокишечной эзофагопластики.

Ключевые слова: послеоперационная стриктура пищевода; лечебная тактика. 